\title{
The Effect of Leg Exercise on Changes in Blood Sugar Levels in the Elderly Patients with Type II Diabetes Mellitus at the Ciracas District Health Center
}

\author{
Akbar Ariyanto*, Fajar Susanti, Erlin Ifadah, Sugeng Hadisaputra \\ Nursing Study Program, Faculty of Health Sciences \\ University Respati Indonesia
}

\begin{abstract}
Increasing prevalence of type 2 Diabetes Mellitus in developed and developing countries is a health problem. Therefore, type 2 Diabetes Mellitus can be prevented by regular exercise, healthy and regular life. The purpose of this study was to determine the effectiveness of foot exercise on changes in blood sugar levels in elderly people with type 2 diabetes mellitus at the Ciracas District Health Center. This type of research is experimental with one group pre-post test design. The population in this study were 36 elderly people with type 2 Diabetes Mellitus in the Ciracas District Health Center. The sample in this study were 18 elderly with type 2 diabetes mellitus in Ciracas District Health Center. The sampling technique used was convenience sampling. Methods of data collection using an observation sheet before and after being given foot exercises. The statistical test used in this study is the paired T test. The results showed that there was no change in blood sugar levels before and after doing foot exercises, the statistical test results obtained a $p$ value of 0.870 , which means $0.870>0.05$, it can be concluded that there is no significant effect between foot exercise and changes in blood sugar levels in elderly patients. Type II diabetes mellitus at the Ciracas Subdistrict Health Center. The absence of any effect of foot exercises on changes in blood sugar levels in the elderly could be due to incomplete exercise, therefore foot exercise training to change blood sugar levels must be done in the elderly.
\end{abstract}

Keywords : Foot exercise, Blood Sugar Levels, DM type 2

\section{Background}

The number of elderly people in Indonesia has increased and is followed by an increase in the frequency of chronic or multi-morbid noncommunicable diseases. According to the Government Regulation of the Republic of Indonesia Number 43 of 2004, an elderly person is someone who has reached the age of 60 years and over (Center for Data and Information, 2017). Based on population projection data, it is estimated that in 2017 there were 23.66 million elderly people in Indonesia, which means that
$10.03 \%$ of the Indonesian population are elderly. It is predicted that the number of elderly people in 2020 is 27.08 million people, in 2025 there are 33.69 million people, in 2030 there are 40.95 million people and in 2035 there are 48.19 million people, which means the number of elderly people in Indonesia will increase every year. . With increasing age, physiological functions decrease due to the aging process so that many non-communicable diseases appear in the elderly. Degenerative problems can reduce the body's resistance so that it is susceptible to infectious 
diseases. The results of the 2013 Riskesdas, the most common diseases in the elderly are NonCommunicable Diseases (PTM), including hypertension, arthritis, stroke, Chronic Obstructive Pulmonary Disease (COPD) and Diabetes Mellitus (DM).

The number of people with Diabetes Mellitus (DM) in the world from year to year shows an increase. Based on data from the International Diabetes Federation (2015). The number of people with DM in the world as many as 387 million people in 2014 increased to 415 million people in 2015 and is estimated to increase to 642 million people in 2040. For the case of diabetes sufferers in Indonesia, there have been almost 9 million people from 2013 to 2018 with a number of deaths occurred in 2015 as many as 5 million people.

Indonesia ranks 6th with 10.3 million patients. Where the first rank is occupied by China with 109.6 million people with DM (IDF, 2015). Most people with DM in Indonesia are aged 60-74 years $(83.3 \%)$ and female $(52.9 \%)$ (Rosyada \& Trihandini, 2010). Deaths due to DM in Indonesia in 2016 were mostly at the age of over 70 years, namely 16,300 elderly men and 34,800 elderly women (WHO, 2016). According to the basic health research report (Rikesdas), the prevalence of DM sufferers in $2013(2.1 \%)$ increased compared to 2007 (1.1\%). DKI Jakarta Province is one of the areas with the highest diabetes prevalence in Indonesia. The prevalence of diabetes in Jakarta based on the results of the
2018 Basic Health Research (Rikesdas) increased from $2.5 \%$ to $3.4 \%$ of a total of 10.5 million people or around 250 thousand residents of DKI Jakarta suffer from diabetes.

Research conducted by Graceistin Ruben, et al (2016), concluded that from the results of measuring the average change in blood sugar levels in the experimental group before doing foot exercise DM was 4.35 and in the control group was 3.56. After being given treatment by doing leg exercises for 7 days in a row, there was an increase in changes in blood sugar levels in the experimental group by 4.85 , while in the control group which was not given constant treatment, it was 3.56 with statistical test results $\mathrm{p}<0,05$, so it can be concluded that doing DM foot exercises can increase changes in blood sugar levels in type 2 DM patients.

\section{RESEARCH METHODS}

This research is a quantitative research method with the type of experimental research. The design used in this study is a one group pre test and post test design. where in this study compared the results of the foot exercise program intervention in the experimental group whose samples were observed before being treated and then after being given treatment the sample was observed again. The population in this study were the elderly who suffered from Diabetes Mellitus at the 
Ciracas District Health Center as many as

36 patients.

\section{RESEARCH RESULT}

Univariate Analysis

Table 1. Distribution of Blood Sugar

Levels Before Giving Foot Exercises to

Elderly Patients with Type II Diabetes

Mellitus at the Ciracas District Health

Center, East Jakarta 2020 (n=18)
GDS Posttest 11,903 262.72 50,498 18

Based on Table 2, it can be seen that from 18 respondents after doing foot exercises for patients with Diabetes Mellitus in the elderly whose blood sugar levels rose from the results of the GDS Pretest as many as 7 respondents (38.9\%) and those who decreased from the results of the GDS Pretest were 11 respondents $(61,1 \%)$.

\begin{tabular}{llll}
\hline $\begin{array}{l}\text { GDS Pretest } \\
\text { massage }\end{array}$ & Foot & Frequency & Percent(\%) \\
\hline$>200 \mathrm{mg} / \mathrm{dL}$ & 16 & $88,9 \%$ & For \\
$<200 \mathrm{mg} / \mathrm{dL}$ & 2 & $11,1 \%$ & \\
\hline Total & 18 & $100 \%$
\end{tabular}

Based on Table 1, it can be seen that from 18 Table 3 Distribution of Ability to Perform Foot Exercises in Elderly Patients with Type II Diabetes Mellitus at the Ciracas District Health Center, East Jakarta

respondents before doing foot exercises for patients with Diabetes Mellitus in the elderly whose blood sugar levels were more than 200 $\mathrm{mg} / \mathrm{dL}$ as many as 16 respondents $(88.9 \%)$ and those below $200 \mathrm{mg} / \mathrm{dL}$ as many as 2 respondents $(11.1 \%)$.

Table 2 Distribution of Blood Sugar Levels

\begin{tabular}{llllll}
$\begin{array}{l}\text { Pre post } \\
\text { intervensi }\end{array}$ & Std. Eror Mean & Mean & Std.Deviation & $\mathrm{N}$ & (p.value) \\
\hline & & & & & \\
GDS Pretest & 14,146 & 265,78 & 60,018 & 18 & 0,870 \\
& & & & & \\
GDS Posttest & 11,903 & 262,72 & 50,498 & 18 & \\
\hline
\end{tabular}
$2020(n=18)$

\begin{tabular}{lll}
\hline GDS Posttest foot massage & Frequency & Persentase (\%) \\
\hline Increased & 7 & $38,9 \%$ \\
Decreased & 11 & Based $\%$ Table 3, it can be seen that of the 18 \\
\hline Total & 18 & $\begin{array}{l}6100 \% \\
\text { respondents at the time of the foot exercise }\end{array}$ \\
\hline
\end{tabular}


intervention for people with Diabetes Mellitus in the elderly who had poor ability to do foot exercises, there were 12 respondents with a percentage $(66.7 \%)$ and those who were good at doing foot exercises were 6 respondents with a percentage $(33.3 \%)$.

\section{BIVARIATE ANALYSIS}

Table 4 Distribution of Average PreIntervention and Post-Intervention Blood Sugar Levels in Elderly Patients with Type II Diabetes Mellitus at the Ciracas District Health Center, East Jakarta in $2020(n=18)$

\begin{tabular}{lll}
\hline $\begin{array}{l}\text { Gerakan senam } \\
\text { kaki }\end{array}$ & Frekuensi & $\begin{array}{l}\text { Presentase } \\
(\%)\end{array}$ \\
\hline $\begin{array}{l}\text { Kemampuan } \\
\text { kurang baik }\end{array}$ & 12 & $66,7 \%$ \\
$\begin{array}{l}\text { Kemampuan } \\
\text { baik }\end{array}$ & 6 & $33,3 \%$ \\
\hline Total & 18 & $100 \%$ \\
\hline
\end{tabular}

Based on Table 4, the results of the independent t-test of differences in blood sugar levels against the foot exercise intervention, the results of the analysis of the average change in blood sugar levels before the foot exercise was 265.78 with a standard deviation of 60.018 in people with Diabetes Mellitus, then after being given foot exercises the changes in levels blood sugar in the elderly who suffer from diabetes mellitus 262.72 seen in the mean value with a standard deviation of 50.498. There is no change in blood sugar levels before and after foot massage, the results of statistical tests obtained p.value 0.870 , which means 0.870 > 0.05 , it can be concluded that there is no significant effect between foot exercise and changes in blood sugar levels in the elderly with type II diabetes mellitus at the Ciracas District Health Center.

\section{DISCUSSION}

Blood sugar levels in the elderly with type 2 diabetes mellitus before being given a foot exercise intervention at the Ciracas District Health Center. The results based on table 5.4 show that the results of research conducted from 18 people, with blood sugar levels before the foot exercise intervention was more than $200 \mathrm{mg} / \mathrm{dL}$ as many as 16 respondents $(88.9 \%)$ and those below 200 $\mathrm{mg} / \mathrm{dL}$ as many as 2 respondents. (11.1\%). The results of the study were based on the ability to perform movements of 18 respondents at the time of performing foot exercise interventions for people with Diabetes Mellitus in the elderly who had poor ability to perform leg exercises, there were 12 respondents with a percentage $(66.7 \%)$ and 
those who were good at performing foot exercises were 6 respondents with a percentage $(33.3 \%)$.

Blood sugar levels in the elderly with type 2 diabetes mellitus after being given a foot exercise intervention at the Ciracas District Health Center. The results of the study based on table 5.5 show that of the 18 respondents after doing foot exercises for patients with Diabetes Mellitus in the elderly whose blood sugar levels rose from the results of the GDS Pretest as many as 7 respondents $(38.9 \%)$ and those who decreased from the results of the GDS Pretest were 11 respondents ( $61.1 \%$ ). Blood sugar levels after being given a foot exercise intervention on average experienced an insignificant decrease in the value of blood sugar levels.

The results of the research conducted by researchers showed changes in blood sugar levels before and after the foot exercise intervention was given. Researchers provide exercise intervention once in three months. The results of these differences were obtained from the results of observation sheets conducted on patients with diabetes mellitus and then analyzed using statistical tests, so that there were differences in blood sugar levels before the foot exercise was 265.78 with a standard deviation of 60.018 in patients with Diabetes Mellitus, then after being given foot exercises changes in blood sugar levels in the elderly who suffer from diabetes mellitus 262,072 seen in the mean value with a standard deviation of 50.498 . There was no change in blood sugar levels before and after doing leg exercises, the results of statistical tests obtained a $p$ value of 0.870 which means $0.870>0.05$, so it can be concluded that there is no significant effect between leg exercises and changes in blood sugar levels in elderly people with diabetes mellitus. type II in the Ciracas District Health Center.

\section{CONCLUSION}

Leg exercises performed by the elderly in this study showed significant changes in blood sugar levels, because changes in blood sugar levels decreased by only 3-4 points, and the results of blood sugar levels did not show the desired changes.

The results showed that there was no effect of leg exercise on changes in blood sugar levels in the elderly. The possible results obtained due to the lack of perfect foot exercises performed by the elderly are caused by several things that must be investigated further. 


\section{Bibliography}

American Diabetes Association (ADA). 2014. Diagnosis and Classification of Diabetes Mellitus. Diabetes Care. https://care.diabetesjournals.org/ content/37/Supplement_1/S14. diakses pada 15 November 2020

Anggraini, S.S. 2017. Pengaruh Senam Kaki Terhadap Kadar Gula Darah Sewaktu Pada Penderita Diabetes Melitus Tipe Ii Di Wilayah Kerja Puskesmas Cawas 1. Yogyakarta: Universitas Aisyiyah Yogyakarta. Tersedia dalam

http://digilib.unisayogya.ac.id/25 09/ (diakses pada 15 November 2020).

Arisman. 2011. Diabetes Mellitus. Dalam: Arisman, ed. Buku Ajar Ilmu Gizi Obesitas, Diabetes Mellitus dan Dislipidemia. Jakarta: EGC, 44-54.

Damayanti, S. 2015. Diabetes Melitus dan Penatalaksanaan Keperawatan. Yogyakarta: Nuha Medika.

Harrison. 2012. Buku Ajar Penyakit Dalam. Jakarta: EGC.

IDF. 2014. IDF Diabetes Atlas. http://www.idf.org/atlasmap/atla smap, 23 November 2020.

Kholifah, S. N. 2016. Keperawatan Gerontik. Pusat pendidikan sumber daya manusia kesehatan badan pengembangan dan pemberdayaan sumber daya manusia kesehatan, 10.

National Institute for Diabetes and Digestive and Kidney Diseases (NIDDK). 2014. Cause of diabetes. NIH Publication

Notoatmodjo,S. 2012. Metodologi Penelitian Kesehatan.Jakarta : Rineka Cipta

Nursalam. 2014. Manajemen Keperawatan: Aplikasi Dalam Praktik Keperawatan Profesional. Jakarta: Salemba Medika

Nursalam. 2015. Metodologi Penelitian Ilmu Keperawatan. Jakarta: Salemba Medika.

Perkumpulan Endokrinologi Indonesia (PERKENI). 2011. Konsensus Pengelolaan Dan Pencegahan Diabetes Melitus Tipe $2 \mathrm{Di}$ Indonesia 2011. Jakarta: Pengurus Besar Perkumpulan Endokrinologi Indonesia.

Perkumpulan Endokrinologi Indonesia (PERKENI). 2015. Konsensus Pengelolaan dan Pencegahan Diabetes Melitus Tipe 2 di Indonesia.

https://pbperkeni.or.id/wpcontent/uploads/2019/01/4.Konsensus-Pengelolaan-danPencegahan-Diabetes-melitustipe-2-di-Indonesia-PERKENI2015.pdf. Diakses pada 04 Desember 2020

Perkumpulan Endokrinologi Indonesia (PERKENI). 2019. Proceeding 
book. https://pbperkeni.or.id/wpcontent/uploads/2019/05/Procee

ding-Book-AEDU-2019.pdf.

Diakses pada 04 Desember 2020

Priyanto, S. 2012. Pengaruh Senam Kaki Terhadap Sensitivitas Kaki Dan Kadar Gula Darah Pada Aggregat Lansia Diabetes Melitus Di Magelang. Jakarta: Universitas Indonesia. Tersedia dalam http://lib.ui.ac.id/file=digital/203 00843T30470\% 20\%20\%Pengaru h\%20senam.pdf (diakses pada 02 Desember 2020).

Priyoto. 2018. NIC (Nursing Intervention Classification) Dalam Keperawatan Gerontik. Jakarta: Salemba Medika.

Purwita, A.N. 2016. Hubungan Dukungan Keluarga Dengan Perubaha Gula Darah Pasien Diabetes Melitus Tipe 2 Di RSUD Kota Madiun. Proposal FK Stikes Bhakti Husada Mulia Madiun

Riset Kesehatan Dasar (RISKESDAS). 2013. www.Riskesdas.com. Diakses pada 13 November 2020.

Rondhianto, 2011. Pengaruh Diabetes Self Management Education Dalam Discharge Planning Behavior Pasie Diabetes Melitus Tipe 2. Thesis FKP. Ubnair . Surabaya . FKP Unair.

Smeltzer, S. C., Bare. G., Hinkle,J. L., cheever,K. H. 2015. Brunner \& Suddarth: Textbook of Medical-Surgical Nursing. Philadelphia: Lippincott Williams \& Wilkins.

Soegondo , 2014. Diagnosis dan Klasifikasi
Diabetes Melitus Terkini dalam buku Penatalaksanaan Diabetes Terpadu sebagai Panduan Penatalaksanaan Diabetes Melitus Bagi Dokter Maupun Educator Diabetes. Jakarta: FKUI.

Soewondo, P, Subekti, 2014. Penatalaksanaan Diabetes Melitus Terpadu. Balai Penerbit. Jakarta: FKUI

Sugiyono. 2010. Metode Penelitian Pendidikan Pendekatan Kuantitatif, kualitatif, dan $R \& D$. Bandung: Alfabeta

Sukesi, N. 2017. Pengaruh Senam Kaki Terhadap Kadar Gula Darah Pada Pasien Dengan Diabetes Melitus. Semarang: Dosen DIII Keperawatan Widya Husada. Tersedia dalam http://stikeswh.ac.id:8082/journ al/index.php/jitk/article/view/5 $\underline{0}$ (diakses pada tanggal 15 November 2020).

Sunaryo, Wijayanti, Rahayu. (2016). Asuhan Keperawatan Gerontik. Yogyakarta : CV ANDI OFFSET

Tandra . 2014. Segala sesuatu yang harus anda ketahui tentang diabetes. Jakarta: Gramedia Pustaka Utama.

Widiyanti, A \& Proverawati. 2010. Senam Kesehatan. Yogyakarta: Nuha Medika

World Health Organization (WHO). 2014. Media Centre. Diabetes. Diakses dari http://www.who.int (diakses pada 15 November 2020). 
Journal Of Ageing And Family (JOAF)

Edition 1, No 1, October 2021 